\title{
A Deep Dive: Does Big Data Improve Maturity in the Developed Capital Markets?
}

\author{
Rajesh Kumar Singh*, Subrata Kumar Mitra \\ Indian Institute of Management Raipur, Raipur, India \\ Email: *rajesh.efpm2013@iimraipur.ac.in
}

How to cite this paper: Singh, R.K. and Mitra, S.K. (2019) A Deep Dive: Does Big Data Improve Maturity in the Developed Capital Markets? Theoretical Economics Letters, 9, 60-74. https://doi.org/10.4236/tel.2019.91006

Received: November 21, 2018

Accepted: January 26, 2019

Published: January 29, 2019

Copyright $\odot 2019$ by author(s) and Scientific Research Publishing Inc. This work is licensed under the Creative Commons Attribution International License (CC BY 4.0).

http://creativecommons.org/licenses/by/4.0/

C) (i) Open Access

\begin{abstract}
Over this decade, the concept of big data has been applied to industries but the capital markets have been traditionally laggard to adoption. Within the financial services' sector, Big Data has gained far more traction within retail banking and insurance due to the increasing desire of these financial institutions to profile and analyze their customers in a similar manner to early adopters of Big Data strategy such as Amazon, Baidu or Google. However, Big Data strategies have begun to make some impacts on few selected areas of the capital markets, including the social media sentiment analysis on the structured and unstructured data for trading, growth in volume, risk analytics, fraud prevention, market surveillance, predictability and forecasting of the equity prices; those are the early sign of the maturity of the capital markets. Technical and theoretical measures have evolved, but still these dimensions of the capital markets have been a mystery for the human beings till now. The Big Data in the form of structured, semi-structured and unstructured socio-economic and demographic information from social media and blogs from consumers has started indicating impacts on the capital markets which can lead to improving the real-time systems and transaction processing, and improving operational efficiency and maturity. The intent of this paper is threefold. First, it aims to bring the clear inference from the past researches to take a holistic analysis of the work done in the emerging area of Big Data and its implications on capital markets. Second, it's to perform a deep analysis on how the influences of Big Data affect the assumptions in connection with Random Walk theory and Efficient Market Hypothesis. Third, it will provide a conclusive theoretical analysis of past research work by the scholars, which can establish the model to refine the nexus between investors' sentiments and assets' prices with advanced techniques in the Big Data. The paper has been divided into 4 broad sections. In the first section, the paper sets the introduction of connecting the dots and setting the context for the two different fields like Big Data and its influences on the capital markets. The second section
\end{abstract}


explains the theoretical premises and frameworks needed for this research and does deep studies of the previous works in this area to establish conclusive references for the future study. The third section carries out the studies of emerging social media and technologies, analysis of the previous research works from the social media and the capital markets perspective. Finally, the fourth section concludes findings with recommendations.

\section{Keywords}

Efficient Market Hypothesis (EMH), Capital Market Line (CML), Capital Asset Pricing Model (CAPM), Security Market Line (SML), High Frequency Trading (HFT), Low Frequency Trading (LFT), Ultra High Frequency Data (UHFD), Data Science, Big Data, Natural Language Processing (NLP), Machine Learning (ML), Artificial Intelligence (AI)

\section{Introduction}

A capital market is a part of the financial system in which debt or equity backed securities are bought and sold. The buying and selling of the equities are generally carried out by the individuals or the institutions. As a trend, these trades are generally long term in nature, which have locks in a period of more than a year. The capital market is a much broader landscape which also includes stock markets which are used to trade the securities. In one of the papers (Hilbert [1] on Big Data for development), he stresses that Big Data delivers the very cost-effective prospect to improve decision-making in critical economic development areas such as economic development, health care, security and resource management through effective decision making process. The use of Big Data to improve the effectiveness of decision-making process also contributes to the theory of economic development. At the verge of big data, crossing Moore's chasm as the capital markets has started focusing on the unstructured data for new avenues for innovation and has offered immense opportunities for growth and sustainability. The concept of "Big" in a retail or scientific environment is different from what is considered to be big in a capital market context. The capital markets tend to deal largely with structured data sets from a more limited set of defined sources-market data vendors, market infrastructures, and counterparties. Some unstructured datasets have, however, become important to capital markets institutions in areas such as sentiment analysis, market surveillance for profiling certain trends and fraud prevention, improving the predictability, maturity and activities in the market and within firms. But these were not traditionally being the data sets of primary importance to the business. There has always been a gap or chasm among innovators, early adopters and laggards for the adoption of discontinuous or disruptive technologies, and that's why Big Data is today in capital markets.

One of the milestone finance theoretical premises published by Fama and Malkiel in Journal of Finance in 1970 [2], with the title "Efficient Capital Mar- 
kets: A Review of Theory and Empirical Work", changed the full perspective of all the scholars and practitioners looking for the predictability and forecasting patterns for the stock market. Fama [3] suggested three levels of the market efficiency "Weak-form" efficiency were security prices, reflecting all information found in the record of past prices and volumes. Prices in "Semi-strong form" of efficiency reflected not only all information found in the record of past prices and volumes but also all other publicly available information whereas prices in "Strong-form" efficiency reflected all the available public information as well as private information. In another milestone paper "Market Efficiency, Long-Term Returns, and Behavioral Finance" in 1998, Fama [4] observed that in line with the market efficiency hypothesis that the capital market anomalies were chance results, the apparent overreaction to information was as common as under reaction, and post-event continuation of pre-event abnormal returns was about as frequent as post-event reversal. He also mentioned that in line with the market efficiency prediction that apparent anomalies could be due to methodology, most long-term return anomalies tended to disappear with reasonable changes in technique.

In the recent days, massive eruptions of the information flow, technological changes and availability of structured and unstructured data for consumption have generated a fresh interest in looking into the efficiency and maturity of the capital market from the fresh perspective. This brings a great intersection of the theoretical premise of the efficient market hypothesis (EMH), Random walk theory [5], circulation of the massive data flow and its consumption through the newer technologically landscape of Big Data. To support this finding, previous scholars such as Singh [6] concluded that adoption of new technologies such as Big Data could drive efficiency and promote productivity. Singh [7] and Singh [8] explained that $R \& D$ helped to create a vehicle to drive these synergies as technology spillovers. To explain their findings, Singh [9] argued that large organizations needed to adopt Big Data aligned information technology strategies in order to reduce costs and their reliance on large manual manpower. One of the strategies for the merger is driven by the technical advancements (Singh [10] and Singh [11]), which can be further refined and matured through Big Data strategies.

\section{Foundation}

The two basic principles of the financial world are foundation and basic premise to carry out the study further Attigeri [12]: 1) Profit cannot be generated out of nothing and 2) No opportunities for arbitrage i.e. there is no potential to generate profit without risk which is also called "No Arbitrage principle". The concept of the efficient capital market stemmed from an incidental discovery by a British statistician Kendall [13] his paper "The Analysis of Economic Time-Series-Part 1: Prices" in 1953 [14] on the behavior of stock and commodity prices. Though the Kendall idea was not completely new, similar idea was proposed in almost forgotten thesis by written 53 years earlier by French doctoral student Bachelier 
[15], accompanying development of the mathematical theory of random processes in reference to Einstein famous work on the Random Brownian Motion of colliding gas molecules ${ }^{1}$. Kendal had expected to find the regular price cycles but he was surprised to observe that they did not seem to exist and he conceived the thought of "Random Walk". The Random walk theory [5] and Attigeri [12] stressed that changes in the stock prices are independent of each other, so the past movement or trend of a market cannot be used to predict the future movement. It is expressed as

$$
\begin{gathered}
V(n)=v(n-1)+c(n) \\
\Delta v(n)=v(n)+d(n)-v(n-1) / v(n)
\end{gathered}
$$

where $\mathrm{v}(n)$ : price of a stock at a time $n$ and $v(n-1)$ : price of the stock at a time $n-1$.

$\Delta v(n)$ : change in the price of the stock at a time $n, d(n)$ : dividend at time $\mathrm{n}$, and $c(n)$ : adjustment term at time $n$.

Since $c(n)$ encompasses the impact of all publicly and privately available information on the stock, which makes the prediction of the pattern of $\Delta v(n)$ very complicated.

While Kendall suggested that stock prices follow a random walk, he implied that the price changes are independent of one another just as the gains and losses in coin tossing game are independent.

In general, investment decisions are aimed to maximize the NPV (Net Present Value), however it is more difficult to add value through the financing decisions because the capital markets are generally very competitive and efficient. In one of literature of the financial economics, Fama introduced the concept of "efficient" capital market which is understood in the normal way that capital markets are generally very competitive and efficient. This was indeed a sweeping hypothesis which is discussed and challenged even today. A efficient market is understood as one in which the market price of the security is an unbiased estimate of its intrinsic value though market price does not equals to intrinsic value at every point in time. This means that price can deviate from intrinsic value but the deviations are random and uncorrelated with any observable variable. If the deviations of market price from intrinsic value are random, it is not possible to consistently identify over or under valued securities. While working on the theme of "Efficiency" Fama [16] mentioned in his paper "Agency Problems and the theory of the firm" that how the separation of security/equity ownership and control, typically of large corporations, can be an efficient form of economic organization.

There are various misconceptions about the efficient market hypothesis one of the very prominent one is that efficient market theory implies that market has perfect forecasting abilities but in reality this hypothesis only implies that security prices impound all available information which does not mean that the market possesses the forecasting abilities.

${ }^{1}$ Principles of Corporate Finance by Brealey Myers Allen, Chapter 14, Efficient Market and Behavioral Finance. 
There are expert discussions and views on the ongoing efficient market hypothesis which fundamentally implies that market establishes the right price of the equity however the alternative paradigm suggests that there is often a divergence between the fundamental value and market price. Eminent experts on this subjects like Graham \& Dodd, Irwin, Manmohan Singh, William Baumol, LC Gupta etc have observed that "Knowledge" and "Information" is only one ingredient in arriving at the stock's price, it is also dependent on bullish enthusiasm, influence or bullish disillusionment etc. ${ }^{2}$

RVL Cooper [17] mentioned that there is contradiction between the quantity theory of money and capital market efficiency. The relationship between the money supply and equity prices refutes the other findings of the capital market efficiency. Using the quantity theory of money, Sprinkel [18] finds that money supply changes could be used to predict the stock prices. However if the capital market is efficient, past information like money supply cannot be used for predicting the stock prices.

Timmermann and Granger [19] mentioned that the efficient market hypothesis gives rise to forecasting tests in the context of a given past information set. However, there are also important differences arising from the fact that market efficiency tests rely on establishing profitable trading opportunities in "real time". As the Forecasters continuously try for the predictable patterns and affect prices when they attempt to exploit trading opportunities. Stable forecasting patterns are therefore unlikely to persist for long periods of time and will self-destruct when discovered by a large number of investors. This gives rise to non-stationarities in the time series of financial returns and complicates the formal tests of market efficiency and the search for successful forecasting pattern.

Based upon all the arguments and discussion, it seems that Efficient Market Hypothesis like all theories is an imperfect and provides limited description of the stock market. However at least for the present, it seems to be better alternative. This hypothesis is too broad and too flexible to be rejected.

\subsection{Finding of Key Papers: Efficient Market Hypothesis}

\begin{tabular}{|c|c|c|c|c|}
\hline S. No. & Year & Authors & Paper title & Major findings \\
\hline 1 & 1900 & Bachelier [15] & Théorie de la spéculation & $\begin{array}{l}\text { The mathematical theory of the random processes based } \\
\text { on Einstein theory of random Brownian motion of } \\
\text { colliding gas molecules }\end{array}$ \\
\hline 2 & 1953 & Kendall [13] & $\begin{array}{l}\text { The Analysis of Economic } \\
\text { Time-Series-Part i: Prices }\end{array}$ & $\begin{array}{l}\text { Kendal could not find the regular stock price cycle and } \\
\text { observed that most likely it doesn't exist }\end{array}$ \\
\hline 3 & 1964 & Cootner $[20]$ & $\begin{array}{l}\text { The Random Character of Stock Market } \\
\text { Prices }\end{array}$ & $\begin{array}{l}\text { The price changes of the stocks are independent to each } \\
\text { other }\end{array}$ \\
\hline 4 & 1964 & Sprinkel [18] & Money and Stock Prices & $\begin{array}{l}\text { The change in the supply of the money could predict the } \\
\text { stock prices }\end{array}$ \\
\hline
\end{tabular}

${ }^{2}$ Financial Management by Prasanna Chandra, Market Efficiency and Financing Decisions. 


\section{Continued}

\begin{tabular}{|c|c|c|c|c|}
\hline 5 & 1970 & Malkiel and Fama [2] & $\begin{array}{l}\text { Efficient Capital Markets: A Review of } \\
\text { Theory and Empirical Work }\end{array}$ & $\begin{array}{l}\text { Three forms of the Capital market's efficiency 1) Weak } \\
\text { 2) Semi Strong and 3) Strong. A market in which prices } \\
\text { always "fully reflect" available information is "efficient" }\end{array}$ \\
\hline 6 & 1974 & Cooper [17] & $\begin{array}{l}\text { Efficient Capital Markets and the } \\
\text { Quantity Theory of Money }\end{array}$ & $\begin{array}{l}\text { The relationship between the money supply and stock } \\
\text { prices seems to refute the other findings of the efficient } \\
\text { capital market }\end{array}$ \\
\hline 7 & 1980 & $\begin{array}{l}\text { Grossman and Stiglitz } \\
{[21]}\end{array}$ & $\begin{array}{l}\text { zOn the Impossibility of Informationally } \\
\text { Efficient Markets }\end{array}$ & $\begin{array}{l}\text { It is not possible to have equilibrium always in the } \\
\text { competitive economy }\end{array}$ \\
\hline 8 & 1980 & Fama [16] & $\begin{array}{l}\text { Agency Problems and the Theory of the } \\
\text { Firm }\end{array}$ & $\begin{array}{l}\text { The separation of security ownership and control, } \\
\text { typical of large corporations, can be an efficient form of } \\
\text { economic organization }\end{array}$ \\
\hline 9 & 1988 & Fischel [22] & $\begin{array}{l}\text { Efficient Capital Markets the Crash and } \\
\text { the Fraud on the Market Theory }\end{array}$ & $\begin{array}{l}\text { The market crash on October } 1987 \text { cast doubt on the } \\
\text { concept of the efficient market hypothesis }\end{array}$ \\
\hline 10 & 1989 & Stein [23] & $\begin{array}{l}\text { Efficient Capital Markets, Inefficient } \\
\text { Firms: A Model of Myopic Corporate } \\
\text { Behavior }\end{array}$ & $\begin{array}{l}\text { In efficient behavior of the myopic corporate managers } \\
\text { mislead the market about their firm's worth and boost } \\
\text { their current earning but in equilibrium market is } \\
\text { efficient }\end{array}$ \\
\hline 11 & 1989 & LeRoy [24] & $\begin{array}{l}\text { Efficient Capital Markets and } \\
\text { Martingales }\end{array}$ & $\begin{array}{l}\text { The theory of efficient capital market is just the theory } \\
\text { of competitive equilibrium applied assets market }\end{array}$ \\
\hline 12 & 1998 & Fama [4] & $\begin{array}{l}\text { Market Efficiency, Long-Term Returns, } \\
\text { and Behavioral Finance }\end{array}$ & $\begin{array}{l}\text { Consistent with the market efficiency prediction, } \\
\text { most long-term return anomalies tend to disappear with } \\
\text { reasonable change in techniques }\end{array}$ \\
\hline 13 & 1998 & Hellström [5] & $\begin{array}{l}\text { A Random Walk through the Stock } \\
\text { Market }\end{array}$ & $\begin{array}{l}\text { The stock price changes are independent to each other, } \\
\text { so past movement cannot be used to predict the future } \\
\text { movement }\end{array}$ \\
\hline 14 & 2004 & $\begin{array}{l}\text { Timmermann and } \\
\text { Granger [19] }\end{array}$ & $\begin{array}{l}\text { Efficient Market Hypothesis and } \\
\text { Forecasting }\end{array}$ & $\begin{array}{l}\text { This gives rise to non-stationarities in the time series } \\
\text { of financial returns and complicates the formal tests of } \\
\text { market efficiency and the search for successful } \\
\text { forecasting pattern }\end{array}$ \\
\hline 15 & 2017 & Burton and Shah [25] & $\begin{array}{l}\text { Efficient Market Hypothesis. CMT } \\
\text { Level I: An Introduction to Technical } \\
\text { Analysis }\end{array}$ & $\begin{array}{l}\text { The EMH hypothesis has to deal with the predictability } \\
\text { of the equity prices in the capital/financial market }\end{array}$ \\
\hline
\end{tabular}

\subsection{Capital Market and Economy}

In the current landscape of the economies, the world's economy could be broadly divided in three categories ${ }^{3}$ based upon the income in three categories Low income, Middle income and High income. In the similar way, the world's capital markets could be divided in three broad categories based upon the efficiency of the capital markets like Weak form of efficiency, Semi strong form of efficiency and Strong form of efficiency. In general, the developed economies like USA shows the characteristics of the strong form of the efficiency however the developing economies like India shows the characteristics of semi strong form of the efficiency.

\section{Social Media and Emerging Technologies}

The big data strategy and algorithms does use the power of high capacity com${ }^{3}$ https://siteresources.worldbank.org/INTRGEP2004/Resources/classification.pdf Accessed on April 28th 2018 
puting to affect the high frequency trading which improves the efficiency in the market however high frequency trading also poses many regulatory challenges for the security and exchange commission. Social media and microblogs affect the risk appetite of the investors. The sentiment and decision-making pattern of the investors are influenced by the continuous flows of the information through the social media which affects the capital markets.

Within the financial services sector, Big Data has gained far more traction within retail banking and insurance sector due to the increasing desire of these financial institutions to profile their customers in a similar manner to early adopters of Big Data strategy such as Amazon, Baidu or Google. Big data is defined as, "data sets with sizes beyond the ability of commonly used software tools to capture, curate, manage, and process data" (Snijders et al.) [26]. However, Big Data strategies have begun to make significant impact in a selected few areas of the capital markets including the sentiment analysis for trading and growth in volume, risk analytics, fraud prevention and market surveillance. The global financial markets were fragmented due to rapid globalization and technological changes (Funk et al.) [27]. In one of study on liquidity, Blocher et al. [28] identified three key components of the financial market like 1) fund management for long term investors, 2) low-frequency trading (LFT) by the traditional brokers and 3) and high-frequency trading (HFT) by proprietary financial firms which used the Big Data and aggregated information to set the trading strategy. The capital market industry has varied data source, which included structured data like traditional banking transaction data and market data which is also called the "system of records". At the same time, it also generates mammoth volume of unstructured data through corporate news, feeds, blogs, micro blogs, macro and micro economic indicators, social media updates and contents. In recent years, capital markets have gone through an unprecedented change, resulting in the generation of massive amounts of high-velocity and heterogeneous data. Similar trends could be observed in the financial services sector as well, where Big Data has been increasingly becoming the most significant, promising, and differentiating asset for the financial services enterprises (Seth et al.) [29]. These massive data troves could be processed through Big Data strategy, tools and techniques which could be game changer. Traditional tools cannot process such large datasets, however the Big Data based approach can analyze structured and un-structured data and create logical pattern to help business to take decisions. The speed and agility of this processing is exponentially faster than that could be done by the traditional mechanism. This provides near real time information with the actionable intelligence which could be used in the decision-making process. The analytical and predictive power of information generated from online big data for the capital market activity is supported by numerous studies ranging from stock markets to housing markets.

Big Data strategy could help the capital market to address key use cases in the area of 1) Trading Strategy, 2) Reporting, 3) Compliance, 4) productivity improvement and maturity and 5) Operational simplifications. Investment banks 
have an untapped opportunity to use Big Data to solve many of their business problems. The age of Big Data offers new creative opportunities across the board. For finance researchers, Big Data allows the field to settle old debates and discover new puzzles. For investment practitioners, the Big Data approach offers limitless possibilities to gain informational advantage over the competition by cleverly analyzing public data sources. Big Data strategies in the capital markets tend to be synonymous with analytical tasks or those related to reporting or governance functions but in the in the recent years the consumption of text-based, audio \& video unstructured data had also been a significant driver for some projects. Regulatory, client, and internal drivers have forced most firms to re-evaluate the core reference data sets on which they are basing their trading, risk management, prediction, forecasting and operational decisions.

\subsection{Capital Markets and Emerging Technologies}

Big Data had been a much misused and misunderstood term within the financial services industry and capital markets for some time. A data driven culture is driving the research field in Finance and Management since the advent of structured, semi-structured and unstructured socio-economic and demographic information from social media, mobile devices, blogs and microblogs. Big Data which encompasses this revolution, involves the usage of new tools for financial professionals and academic researchers due to the size of data involved. In the capital market, the technology focus is often towards improving real-time systems, transaction processing, operational efficiency and establishing data warehouses of structured data. The adoption of discontinuous or disruptive technologies, there is a gap or chasm between innovators and early adopters and that is where big data is today in capital markets. Some unstructured data sets have however, become important to capital markets institutions in areas such as sentiment analysis and market surveillance for profiling certain trends and activities in the market and within firms, but there have not traditionally been the data sets of primary importance to the business. The Big Data refers to data that could be categorized in the four categories: 1) Volume \& Quantity of the data generated, 2) Velocity \& Speed at which data is generated, 3) Variety \& Types of data like test, audio and video etc. and 4) Veracity \& Integrity and quality of the data being processed. In the context of Big Data, it was represented by $4 \mathrm{Vs}$ (Variety, Velocity, Veracity and Volume) but while understanding its context in terms of capital market, it is important to consider the other attributes of the data (Variability, Value and Visualization). These 7 Vs made the complete view of the data in the context of capital markets. The large-scale enterprise level NLPs affect the capital market strategy for the HFTs and LFTs. These new emerging technologies and cutting edge technologies are bound to have significant impact on the capital markets in the developed and emerging economies. Big data platform has been in the forefront to bring innovation in the areas of Data Science, Artificial Intelligence, Machine Learning, Deep Learning and Nat- 
ural language processing (NLP). At the verge of big data crossing Moore's chasm as the capital markets has started focusing on the unstructured data for new avenues for innovation and has offered immense opportunities for growth and sustainability.

\subsection{Big Data and Capital Market Efficiency}

In the world of finance, the Efficient Market Hypothesis (EMH) asserts that financial markets were "informationally efficient" which means current stock prices were already reflecting all known information (structured or unstructured) and all occurred events and facts. Therefore, investors cannot make excess profits from the market if their trading strategies are based on known information, because market prices are efficiently collecting and aggregating various information and keep changing without delay (Zhang and Skiena) [30]. Enterprise headquarters faces a tradeoff between the cost of attaining an accurate private information and the value of the information, this could lead to the inefficacy in the capital market. Foster [31] studied the efficiency and inefficiency of the capital market and explained the influence of information on the capital market. Fama [32] made the simple hypothesis that security prices fully reflect all available information considering the precondition of that information and trading costs, the costs of getting prices to reflect information, are always zero. It is clear that those who arbitrage make no return from their costly activity in case market is ideally information efficient. Hence, the assumptions that all markets, including that for information, are always in equilibrium and always perfectly arbitraged are inconsistent. In the advent of structured and un-structured information flow in the capital market through the social media, the role of information becomes even more relevant. In case the access of information with all the actors in the capital market not in equilibrium, then it leads the market toward arbitrage and makes less efficient. However effective usage of the Big Data information could reduce the opportunity of arbitrage and make it more efficient. Fama [32] was also of the opinion that predictability of stock returns based upon the dividend yields is not in itself evidence for or against market efficiency. While understanding the behavior of the capital market, Sharpe [33] mentioned that to predict the behavior of capital markets in the state of equilibrium, capital asset prices have adjusted so that the investor, if he follows rational procedures through diversification is able to attain desired point along a capital market line. Investor should be able to absorb all the available information and adjust and diversify its portfolio so that he could attain the desired goal along the Capital Market Line (CML).

It was difficult to observe the investors views on the capital markets and understand the decision-making process before the advent of the Big data. With the ubiquity of information technology and the Internet, an increasing number of investors are gathering information from the Internet for analysis. Ye and $\mathrm{Li}$ [34] observed that Google processed 2 million searches per minute in 2012, 204,166,667 emails were sent per minute, Twitter users posted approximately 
100,000 tweets per minute pertaining to the capital markets. In one study, Bartov et al. [35] aggregated the opinion from individual tweets to successfully predict a firm's forthcoming quarterly earnings and announcement returns. In order to study the impact of the microblogging, Jin et al. [36] observed a significant impact on the increase in the relative trading volume as well as the decreases in the daily expected stock return and firm-level volatility. In similar lines, while studying the impact of the financial news in the media Nagata and Inui [37] observed that there is intrinsic impact on the movements of the financial markets. While Big Data is spreading, a very convincing evidence is observed by Moat et al. [38], which infers that online data and information can give new insights into real-world which could affect the collective decision making and can even anticipate future actions in the capital markets. In the field of Behavioral economics Bollen et al. [39] observed that emotions can profoundly affect the individual behavior and decision-making which could even be extended to even predictive of economic indicators. Zhang et al. [40] extended the research even further and observed based upon the analysis of the Twitter feed on daily basis and its correlation with the indices (NASDAQ, S\&P 500, and Dow Jones), that emotional tweets percentage is significantly negatively correlated with key indices in the USA market. This is significant revelation which indicates the impact of the blogs and microblogs on the capital market of the developed countries like USA. When people are pessimistic or uncertain about the future, they will be more cautious to invest and trade. So, capturing the collective mind-especially people's mood becomes one possible way to predict the stock market movement. While studying the human emotional and its influences on the capital market, Sharpe [33] observed that human state of emotion could influence decisions even in the capital market and the investment decision.

\subsection{Finding of Key Papers: Big Data and Capital Markets}

\begin{tabular}{|c|c|c|c|c|c|}
\hline S. No. & Year & Authors & Paper title & $\begin{array}{l}\text { Does big data } \\
\text { improve maturity in } \\
\text { the capital markets }\end{array}$ & Major findings \\
\hline 1 & 2017 & $\begin{array}{l}\text { Seddon and } \\
\text { Currie }[41]\end{array}$ & $\begin{array}{l}\text { A Model for Unpacking Big Data Analytics } \\
\text { in High-Frequency Trading }\end{array}$ & Accepted & $\begin{array}{l}\text { Big data influenced the HFT significantly } \\
\text { and caused competitive asymmetry } \\
\text { between HFT and LFT }\end{array}$ \\
\hline 2 & 2017 & Singh $[8]$ & $\begin{array}{l}\text { Keeping It Simple: Comparative Analysis } \\
\text { of TFP across Manufacturing Industries } \\
\text { and Major States of India }\end{array}$ & Accepted & $\begin{array}{l}\text { Recommends on the acceptance of the } \\
\text { technology for the productivity } \\
\text { improvement }\end{array}$ \\
\hline 3 & 2017 & Ye and $\mathrm{Li}[34]$ & $\begin{array}{l}\text { Internet Big Data and Capital Markets: } \\
\text { A Literature Review }\end{array}$ & Accepted & $\begin{array}{l}\text { The continuous flow of the information } \\
\text { influences the investors decisions in the } \\
\text { capital markets }\end{array}$ \\
\hline 4 & 2017 & Singh $[10]$ & Merge or Acquire-A Strategic Framework & Accepted & $\begin{array}{l}\text { Studies and recommends on the } \\
\text { acceptance of the technology in the } \\
\text { merger and acquisition }\end{array}$ \\
\hline 5 & 2016 & $\begin{array}{l}\text { Seth and } \\
\text { Chaudhary [29] }\end{array}$ & $\begin{array}{l}\text { Phantom Liquidity and High-Frequency } \\
\text { Quoting }\end{array}$ & Accepted & $\begin{array}{l}\text { High-frequency trading firms behave as } \\
\text { agents who could bring efficiency to the } \\
\text { capital market }\end{array}$ \\
\hline
\end{tabular}




\section{Continued}

62016 Bartov et al. ${ }^{[35]}$ Earnings and Stock Returns? $2016 \quad$ Jin et al. [36]

Has Microblogging Changed Stock Market Behavior? Evidence from China

$2016 \quad$ Singh [7]

9

2016 Singh [6]

Singh $[6]$

Seth and

10

2015

2015

Attigeri et al.

[12]

App

Stock Market

R\&D Spillovers \& Productivity Growth: Evidence from Indian Manufacturing

Do Technology Spillovers Accelerate Performance of Firms?

12

2015 Tian et al. [42]

Latency Critical Big Data Computing in Finance

Shorter et al. High-Frequency Trading: Background,

Funk and Hirschman [27]

Derivatives and Deregulation: Financial Innovation and the Demise of

Glass-Steagall

Does High-Speed Trading Enhance Nagata and Inui Market Efficiency? Empirical Analysis [37] on "Arrowhead" of the Tokyo Stock Exchange

Moat et al. [38]

17 2013

Aldridge [14]

Using Big Data to Predict Collective Behavior in the Real World

Angel and Fairness in Financial Markets:

18

2013 McCabe [44]

Market Microstructure and the Risks of High-Frequency Trading The Case of High Frequency Trading

Aï-Sahalia High Frequency Traders: and Saglam [45] Taking Advantage of Speed

\begin{tabular}{|c|c|c|c|}
\hline 20 & 2013 & $\begin{array}{l}\text { Alanyali et al. } \\
\text { [46] }\end{array}$ & $\begin{array}{l}\text { Quantifying the Relationship between } \\
\text { Financial News and the Stock Market }\end{array}$ \\
\hline 21 & 2012 & $\begin{array}{l}\text { Snijders } \\
\text { et al. [26] }\end{array}$ & $\begin{array}{l}\text { Big Data: Big Gaps of Knowledge in the } \\
\text { Field of Internet Science }\end{array}$ \\
\hline
\end{tabular}

Accepted

Accepted

Accepted

Accepted

Accepted

Accepted

Observed positive association between the aggregate opinion and the immediate abnormal stock price reaction to the quarterly earnings announcement

Observed significant impact of microblogging to increase the relative trading volume as well as the decreases in the daily expected stock return

Technology influences productivity

$\mathrm{R} \& \mathrm{D}$ promote the adoption of new technologies such as big Data and Machine Learning

Big Data in finance will evolve to influence the trading the pattern of the investors

In the technical analysis and fundamental research scholar found that social media has influence on the stock prices

Big data and Analytics based computing could benefit today's banking and financial organizations to achieve more intelligent trading in the capital market

High frequency trading will keep on posing the regulatory challenges with the development of technology

Big Data implications on the HFT trading is highly tilted due to technology

High efficiency trading enhances marketing efficiency

Observed the predictive effect of the Big Data analysis in the financial world

Accepted

High frequency trading reduces the arbitrage due to gap in information

Impact of High frequency trading was put into question as the fair practice in the capital market

High Frequency traders could take the advantage of the speed to influence the capital market in their favour

Observed that movements in financial Accepted markets and movements in financial news are intrinsically interlinked

Observed that Big Data could bridge the gap in knowledge in the capital markets and reduce efficiency 


\section{Continued}

\begin{tabular}{|c|c|c|c|c|c|}
\hline 22 & 2012 & Easley et al. [47] & $\begin{array}{l}\text { The Volume Clock: Insights into the } \\
\text { High-Frequency Paradigm }\end{array}$ & Accepted & $\begin{array}{l}\text { High frequency trading has insightful } \\
\text { impact on the efficiency of the capital } \\
\text { market }\end{array}$ \\
\hline 23 & 2011 & Bollen et al. [39] & Twitter Mood Predicts the Stock Market & Accepted & $\begin{array}{l}\text { Behavioral economics tells that emotions } \\
\text { can profoundly affect individual behavior } \\
\text { and decision-making }\end{array}$ \\
\hline 25 & 2010 & $\begin{array}{l}\text { Zhang and } \\
\text { Skiena [30] }\end{array}$ & $\begin{array}{l}\text { Trading Strategies to Exploit Blog and News } \\
\text { Sentiment }\end{array}$ & Accepted & $\begin{array}{l}\text { Large scale natural language processing } \\
\text { (NLP) system did affect the capital market } \\
\text { strategy for the HFT and LFTs }\end{array}$ \\
\hline 26 & 2010 & $\begin{array}{l}\text { Gilbert and } \\
\text { Karahalios [48] }\end{array}$ & Widespread Worry and the Stock Market & Accepted & $\begin{array}{l}\text { Our emotional state influences our choices } \\
\text { even in the capital markets }\end{array}$ \\
\hline 27 & 1991 & $\begin{array}{l}\text { Fama } \\
{[32]}\end{array}$ & Efficient Capital Markets: II & & $\begin{array}{l}\text { Security prices fully reflect all available } \\
\text { information }\end{array}$ \\
\hline 28 & 1979 & Foster [31] & Briloff and the Capital Market & Accepted & $\begin{array}{l}\text { Influence of the information on the } \\
\text { Capital market efficiency and inefficiency } \\
\text { was observed }\end{array}$ \\
\hline 29 & 1964 & Sharpe [33] & $\begin{array}{l}\text { Capital Asset Prices: A Theory of Market } \\
\text { Equilibrium under Conditions of Risk. }\end{array}$ & Accepted & $\begin{array}{l}\text { Capital assets prices achieve equilibrium } \\
\text { near the Capital market line (CML) }\end{array}$ \\
\hline
\end{tabular}

\section{Concluding Remarks}

The theoretical premises starting from the Random walk theory and Efficient Market Hypothesis indicate that predictability of the stock prices, creating a pattern in the movement of capital markets based upon the past movement is a very complex task. All the studies in the past related to impacts of the Big Data and its influences on the capital markets indicate that information asymmetry can be reduced to a significant level. However, many other macro variables like availability of the internet to all the investors, speed, access to the relevant information, costs of information and biasness in the content on the social media can provide opportunity for inefficiency in the market. Most of the scholars acknowledge during their researches and analyses that Big Data has started playing significant influences on the capital markets and decision-making process. It will further evolve and use the continuous flow of information through defined and non-defined sources such as social media, microblogs as part of their Big Data strategy to do the sentiment analysis and improve the decision moments to improve the maturity and minimize the inefficiency in the capital markets. In this context, the fundamental analysis based upon the Big Data flow from the industry draws a strong attention to carrying out further researches in the perspective of Random Walk theory, theory of economic development and Efficient Market Hypothesis.

\section{Conflicts of Interest}

The authors declare no conflicts of interest regarding the publication of this pa- 
per.

\section{References}

[1] Hilbert, M. (2013) Big Data for Development: From Information to Knowledge Societies.

[2] Malkiel, B.G. and Fama, E.F. (1970) Efficient Capital Markets: A Review of Theory and Empirical Work. The journal of Finance, 25, 383-417. https://doi.org/10.1111/j.1540-6261.1970.tb00518.x

[3] Fama, E.F. and French, K.R. (1997) Industry Costs of Equity. Journal of Financial Economics, 43, 153-193. https://doi.org/10.1016/S0304-405X(96)00896-3

[4] Fama, E.F. (1998) Market Efficiency, Long-Term Returns, and Behavioral Finance. Journal of Financial Economics, 49, 283-306. https://doi.org/10.1016/S0304-405X(98)00026-9

[5] Hellström, T. (1998) A Random Walk through the Stock Market. Doctoral Dissertation, Department of Computing Science, Umea University, Umeå.

[6] Singh, A.P. (2016) Do Technology Spillovers Accelerate Performance of Firms? Unravelling a Puzzle from Indian Manufacturing Industry.

[7] Singh, A.P. (2016) R\&D Spillovers \& Productivity Growth: Evidence from Indian Manufacturing. Indian Journal of Industrial Relations, 51, 563-579.

[8] Singh, A.P. (2017) Keeping It Simple: Comparative Analysis of TFP across Manufacturing. Industries and Major States of India. Theoretical Economics Letters, 7, 1821. https://doi.org/10.4236/tel.2017.76124

[9] Singh, A.P. (2018) Does Size Matter?-The Effect of Size of Production Workers, Management Staff and Proprietors on Productivity. Theoretical Economics Letters, 8, 2290. https://doi.org/10.4236/tel.2018.811149

[10] Singh, A.P. (2017) Merge or Acquire-A Strategic Framework.

[11] Singh, A.P. (2017) Does FDI Promote Productivity? A Deep Dive. Indian Journal of Industrial Relations, 52.

[12] Attigeri, G.V., MM, M.P., Pai, R.M. and Nayak, A. (2015) Stock Market Prediction: A Big Data Approach. TENCON 2015-2015 IEEE Region 10 Conference, Macao, 1-4 November 2015, 1-5.

[13] Kendall, M.G. and Hill, A.B. (1953) The Analysis of Economic Time-Series-Part i: Prices. Journal of the Royal Statistical Society. Series A (General), 116, 11-34. https://doi.org/10.2307/2980947

[14] Aldridge, I. (2013) Market Microstructure and the Risks of High-Frequency Trading.

[15] Bachelier, L. (1900) Théorie de la spéculation. Annales scientifiques de PÉcole Normale Supérieure, 17, 21-86. https://doi.org/10.24033/asens.476

[16] Fama, E.F. (1980) Agency Problems and the Theory of the Firm. Journal of Political Economy, 88, 288-307. https://doi.org/10.1086/260866

[17] Cooper, R.V. (1974) Efficient Capital Markets and the Quantity Theory of Money. The Journal of Finance, 29, 887-908. https://doi.org/10.1111/j.1540-6261.1974.tb01489.x

[18] Sprinkel, B.W. (1964) Money and Stock Prices. RD Irwin, Homewood.

[19] Timmermann, A. and Granger, C.W. (2004) Efficient Market Hypothesis and Forecasting. International Journal of Forecasting, 20, 15-27.

https://doi.org/10.1016/S0169-2070(03)00012-8 
[20] Cootner, P.H. (1964) The Random Character of Stock Market Prices.

[21] Grossman, S.J. and Stiglitz, J.E. (1980) On the Impossibility of Informationally Efficient Markets. The American Economic Review, 70, 393-408.

[22] Fischel, D.R. (1988) Efficient Capital Markets the Crash and the Fraud on the Market Theory. Cornell Law Review, 74, 907.

[23] Stein, J.C. (1989) Efficient Capital Markets, Inefficient Firms: A Model of Myopic Corporate Behavior. The Quarterly Journal of Economics, 104, 655-669. https://doi.org/10.2307/2937861

[24] LeRoy, S.F. (1989) Efficient Capital Markets and Martingales. Journal of Economic Literature, 27, 1583-1621.

[25] Burton, F.E.T. and Shah, S.N. (2017) Efficient Market Hypothesis. CMT Level I 2017: An Introduction to Technical Analysis.

[26] Snijders, C., Matzat, U. and Reips, U.D. (2012) "Big Data”: Big Gaps of Knowledge in the Field of Internet Science. International Journal of Internet Science, 7, 1-5.

[27] Funk, R.J. and Hirschman, D. (2014) Derivatives and Deregulation: Financial Innovation and the Demise of Glass-Steagall. Administrative Science Quarterly, 59, 669-704. https://doi.org/10.1177/0001839214554830

[28] Blocher, J., Cooper, R., Seddon, J. and Vliet, B.V. (2016) Phantom Liquidity and High-Frequency Quoting. The Journal of Trading, 11, 6-15. https://doi.org/10.3905/jot.2016.11.3.006

[29] Seth, T. and Chaudhary, V. (2015) Big Data in Finance.

[30] Zhang, W. and Skiena, S. (2010) Trading Strategies to Exploit Blog and News Sentiment. Proceedings of the 4 th International AAAI Conference on Weblogs and Social Media, Washington DC, 23-26 May 2010, 375-378.

[31] Foster, G. (1979) Briloff and the Capital Market. Journal of Accounting Research, 17, 262-274. https://doi.org/10.2307/2490317

[32] Fama, E.F. (1991) Efficient Capital Markets: II. The Journal of Finance, 46, 1575-1617. https://doi.org/10.1111/j.1540-6261.1991.tb04636.x

[33] Sharpe, W.F. (1964) Capital Asset Prices: A Theory of Market Equilibrium under Conditions of Risk. The Journal of Finance, 19, 425-442.

[34] Ye, M. and Li, G. (2017) Internet Big Data and Capital Markets: A Literature Review. Financial Innovation, 3, 6. https://doi.org/10.1186/s40854-017-0056-y

[35] Bartov, E., Faurel, L. and Mohanram, P.S. (2016) Can Twitter Help Predict Firm-Level Earnings and Stock Returns?

[36] Jin, X., Shen, D. and Zhang, W. (2016) Has Microblogging Changed Stock Market Behavior? Evidence from China. Physica A: Statistical Mechanics and Its Applications, 452, 151-156. https://doi.org/10.1016/j.physa.2016.02.052

[37] Nagata, S. and Inui, K. (2014) Does High-Speed Trading Enhance Market Efficiency? Empirical Analysis on "Arrowhead" of the Tokyo Stock Exchange. The Journal of Trading, 9, 37-47. https://doi.org/10.3905/jot.2014.9.4.037

[38] Moat, H.S., Preis, T., Olivola, C.Y., Liu, C. and Chater, N. (2014) Using Big Data to Predict Collective Behavior in the Real World. Behavioral and Brain Sciences, 37, 92-93. https://doi.org/10.1017/S0140525X13001817

[39] Bollen, J., Mao, H. and Zeng, X. (2011) Twitter Mood Predicts the Stock Market. Journal of Computational Science, 2, 1-8. https://doi.org/10.1016/j.jocs.2010.12.007

[40] Zhang, X., Fuehres, H. and Gloor, P.A. (2011) Predicting Stock Market Indicators through Twitter "I Hope It Is Not as Bad as I Fear". Procedia-Social and Behavioral 
Sciences, 26, 55-62. https://doi.org/10.1016/j.sbspro.2011.10.562

[41] Seddon, J.J.J.M. and Currie, W.L. (2017) A Model for Unpacking Big Data Analytics in High-Frequency Trading. Journal of Business Research, 70, 300-307. https://doi.org/10.1016/j.jbusres.2016.08.003

[42] Tian, X., Han, R., Wang, L., Lu, G. and Zhan, J. (2015) Latency Critical Big Data Computing in Finance. The Journal of Finance and Data Science, 1, 33-41. https://doi.org/10.1016/j.jfds.2015.07.002

[43] Shorter, G. and Miller, R.S. (2014) High-Frequency Trading: Background, Concerns, and Regulatory Developments. CRS Report, 43608.

[44] Angel, J.J. and McCabe, D. (2013) Fairness in Financial Markets: The Case of High Frequency Trading. Journal of Business Ethics, 112, 585-595. https://doi.org/10.1007/s10551-012-1559-0

[45] Aït-Sahalia, Y. and Saglam, M. (2013) High Frequency Traders: Taking Advantage of Speed (No. w19531). National Bureau of Economic Research. https://doi.org/10.3386/w19531

[46] Alanyali, M., Moat, H.S. and Preis, T. (2013) Quantifying the Relationship between Financial News and the Stock Market. Scientific Reports, 3, Article No. 3578. https://doi.org/10.1038/srep03578

[47] Easley, D., López de Prado, M.M. and O'Hara, M. (2012) The Volume Clock: Insights into the High-Frequency Paradigm. The Journal of Portfolio Management, 39, 19-29. https://doi.org/10.3905/jpm.2012.39.1.019

[48] Gilbert, E. and Karahalios, K. (2010) Widespread Worry and the Stock Market. Proceedings of the 4th International AAAI Conference on Weblogs and Social Media, Washington DC, 23-26 May 2010, 59-65. 